\title{
On the Neglected Shifting balance theory, Bateson-Dobzhansky- Muller model \& Quantum evolution plus the Role of Mitochondrial Membrane Potential (MMP) Impact on COVID-19
}

Sorush Niknamian

Military Medicine, Liberty University (LU), VA, USA. Fellow Member of International Society of Infectious Disease (ISID)

*Corresponding Author: Sorush Niknamian, Military Medicine, Liberty University (LU), VA, USA. Fellow Member of International Society of Infectious Disease (ISID).

Received date: February 20, 2021: Accepted date: April 20, 2021: Published date: July 19, 2021

Citation: Niknamian S, (2021) On the Neglected Shifting balance theory, Bateson-Dobzhansky-Muller model \& Quantum evolution plus the Role of Mitochondrial Membrane Potential (MMP) Impact on COVID-19. J.Clin Case Rep and Stu 2(3); DOI: 10.31579/2690-8808/065

Copyright: $\odot$ 2021: Sorush Niknamian. This is an open access article distributed under the Creative Commons Attribution License, which permits unrestricted use, distribution, and reproduction in any medium, provided the original work is properly cited.

\begin{abstract}
Background: Approximately $80 \%$ of all viruses are RNA viruses and they contain their specific RNA helicases. Defective RNA helicases have been linked to infectious diseases (Viral Infections).

Materials and Methods: The articles have gone through many types of research from the beginning of the epidemic of Coronaviruses through history and we introduced the neglected hypothesis of Shifting balance theory, Bateson-Dobzhansky-Muller model \& Quantum evolution. In the ancestral population, the genotype is AABB. When two populations become isolated from each other, new mutations can arise. In one population A evolves into a, and in the other B evolves into b. When the two populations hybridize it is the first time A and B interact with each other. When these alleles are incompatible, we speak of Dobzhansky-Muller incompatibilities plus the role of MMA in mitochondria in spreading SARS-CoV-19 through populations and the result of an infection in COVID-19.

Results: In viruses specifically COVID-19, Ribosomal Frameshift is programmed to allows the virus to encode multiple types of proteins from the same mRNA. HIV-1 (human immunodeficiency virus), RSV (Rous sarcoma virus), and all types of influenza viruses use Ribosomal Frameshift. they rely on frameshifting to create a proper ratio of normal translation and trans-frame (encoded by frameshifted sequence) proteins. Notably, its use in viruses is primarily for compacting more genetic information into a shorter amount of genetic material.

Conclusion: to find the genome sequence of COVID-19 we also used Nanopore sequencing that introduced and manufactured by Oxford scientists, due to differences in the action of infection in the host, we could not reach any results since the Novel Virus has not a stable genome (which is quite dynamic) since through our deep research, each virus contains its specific genome sequencing and we cannot claim that COVID-19 has one specific genome sequence like MERS-CoV, SARS-CoV or any types of viruses which has been discovered and contains their specific genome.

Keywords: Shifting balance theory, COVID-19, MMP, Bateson-Dobzhansky-Muller model \& Quantum evolution
\end{abstract}

\section{Introduction}

Coronaviruses were discovered in the late 1930s [1]. Arthur Schalk and M.C. Hawn Found out in 1931 a novel respiratory infectious disease which call nowadays Coronavirus Disease, in North Dakota. The infected chickens' mortality rate was 40 percent to 90 percent which was really important [2]. Fred Beaudette and Charles Hudson isolated and cultivated the infectious bronchitis virus which caused Coronavirus Disease [3]. In 1940, during the second world war, two more animal coronaviruses, mouse hepatitis virus (MHV), and transmissible gastroenteritis virus (TGEV) were detected and isolated [4]. It was not recognized by the scientists that at that time that these three different viruses were related to Coronavirus [7]. Human coronaviruses were discovered in the 1960s [5-
6]. They were cultivated and isolated using two different patterns in the UK and the United States of America. [8] E.C. Kendall, Malcom Byone, and David Tyrrell in 1960 isolated from a male human a new common cold virus which called B814 [9-11]. The virus, unfortunately, could not be able to be cultivated using first standard techniques which had successfully cultivated rhinoviruses, adenoviruses, and other known common cold viruses. In 1965, Tyrrell and Byone [12]. The new cultivating method was discovered and introduced to the laboratory by Bertil Hoorn [13]. The isolated virus when intranasally inoculated into volunteers caused a cold and was inactivated by ether which indicated it had a lipid envelope [14-15]. At the same time, Dorothy Hamre [16] and John Procknow from the University of Chicago isolated 229E virus from medical students, that they grew in their kidney tissue culture. The 
novel/new virus $229 \mathrm{E}$, like the virus $\mathrm{B} 814$, when inoculated into volunteers caused a cold and was inactivated by ether. [17] B814 and $229 \mathrm{E}$ viruses were imaged by electron microscopes in 1967 by Scottish virologist June Almeida at St. Thomas Hospital in London. [18-19] Not only B814 and 229E viruses were related to each other, but also they were morphologically being in relation to infectious bronchitis virus (IBV). [20] A research group at the NIH at the same year were able to isolate another member of this novel group of viruses by using organ culture and named the virus strain OC43. [21] Like B814, 229E, and IBV, the new cold virus OC43 had distinctive when observed with the electron microscope. [22-23] The IBV-like novel cold viruses were shown to be morphologically related to the mouse hepatitis virus. [24] This new group of IBV-like viruses discovered as coronaviruses after their distinctive morphological appearance. [25] Human coronavirus 229E and OC43 continued to be studied for years. [26-27] The coronavirus strain B814 was lost. It is not known which present human coronavirus it was. [28] Other human coronaviruses discovered and named SARS-CoV in 2003, HCoV NL63 in 2004, HCoV HKU1 in 2005, MERS-CoV in 2012, and SARS-CoV-2 in 2019 which we call it COVID-19. [29-30] There have also been a large number of animal coronaviruses identified since the 1960s which shows these strains of viruses are high in number and very difficult to be studied one by one. [31]

\section{Origin}

The recent common ancestor (MRCA) of all coronaviruses is estimated to have existed in $8000 \mathrm{BCE}$, although some models place the common ancestor in 55 million years or more, implying long term co-evolution with bat and avian species. [32] The most recent common ancestor of the alpha-coronavirus has been placed in $2400 \mathrm{BCE}$, of the beta-coronavirus line at $3300 \mathrm{BCE}$, of the gamma-coronavirus line at $2800 \mathrm{BCE}$, and of the delta-coronavirus line at about 3000 BCE. Bats and birds, as warmblooded flying vertebrates, are an ideal natural reservoir for the coronavirus gene pool. Bats are the reservoir for alpha-coronaviruses and beta-coronavirus However; birds are the reservoir for gammacoronaviruses and delta-coronaviruses. The large number and global range of bat and avian species that host viruses have enabled extensive evolution and dissemination of coronaviruses from the first till today which means these species are the best hosts for evolution of Coronaviruses. [33]

Most human Coronaviruses have their origin in bats. [34] The human Coronavirus strain NL63 has a common ancestor with a bat coronavirus (ARCoV.2) between 1190 and 1449 CE. [35] The human coronavirus strain 229E shared a common ancestor with a bat coronavirus (GhanaGrp1 Bt CoV) between 1686 and 1800 CE. [36] Recently, alpacacoronavirus and human coronavirus strain 229E diverged sometime before 1960. [68] MERS-CoV emerged in humans from bats through the intermediate host of camels. [37] MERS-CoV, related to several bat coronavirus species, appears to have diverged from these several centuries ago. [38] The most closely related bat coronavirus and SARSCoV diverged in 1986. [39] A possible line of evolution of SARS coronavirus and keen-bat-coronaviruses is that SARS related coronaviruses evolved in bats for a long period of time. The ancestors of SARS-CoV first infected leaf-nose bats of the genus Hipposideridae; they spread to horseshoe bats in the species Rhinolophidae, then to civets, and finally to humans. [40-41]

All discussions above can be reduced in words to: (SARS-CoV to Hipposideridae to Rhinolophidae to Civets to Humans).
Unlike other Beta-coronaviruses, bovine-coronavirus of the species Betacoronavirus 1 and subgenus Embecovirus is thought to have originated in rodents and not in bats. [42-43] In the 1790s, equine coronavirus diverged from the bovine coronavirus after a cross-species jump. [44] Later in the 1890s, human coronavirus OC43 diverged from bovine coronavirus after another cross-species spillover event. [45-46] It is speculated that the flu pandemic of 1890 may have been caused by this spillover event, and not by the influenza virus, because of the related timing, neurological symptoms, and unknown causative agent of the pandemic. [47] Besides causing respiratory infections, human coronavirus OC43 is also suspected of playing a role in neurological diseases. [48] In the 1950s, the human coronavirus strain OC43 began to turned into the present genotypes. [49] Phylogenetically, mouse hepatitis virus which is called Murine coronavirus, that infects the mouse's liver and central nervous system, [50] is related to human coronavirus OC43 and bovine-coronavirus. Human coronavirus HKU1, like the aforementioned viruses, also has its origins in rodents. [51] Well-known rodents include mice, rats, squirrels, prairie dogs, chipmunks, chinchillas, porcupines, beavers, guinea pigs, hamsters, gerbils, and capybaras. Rabbits, hares, and pikas.

\section{Materials and Methods}

As described in above lines, SARS-CoV-2 is a complex virus. the genome of the virus differs from one person to another like fingerprints in humans and the reason behind this phenomenon is the amount of tRNA and the metabolism or better called Mitochondrial Function of the person which is based on the amount of ATP releasing from the Mitochondria of each cell and loss of MMP (mitochondrial membrane permeabilization) which is the reason behind the cause of cell apoptosis. Mitochondrial ATP needs proteins from the nuclear and mitochondrial genomes. ROS (Reactive Oxygen Species) disrupt the oxidative production of ATP, which is needed for normal cellular function, Because of the damage of mtDNA that disrupts the normal synthesis of proteins which is needed for mitochondria function, making them suitable targets for attacks by ROS produced during infections by viruses including Coronaviruses that raises ROS in the host cell which affects Mitochondria and leads to loss of MMP. [52]

Proteins are translated by reading tri-nucleotides on the mRNA strand, also known as codons, from one end of the mRNA to the other (from the $5^{\prime}$ to the $3^{\prime}$ end). Each codon is translated into a single amino acid. Therefore, a shift of any number of nucleotides that is not divisible by 3 in the reading frame will result in subsequent codons to be read differently. [53] This effectively changes the ribosomal reading frame. In viruses specially COVID-19, Ribosomal Frameshift is programmed to allow the virus to encode multiple types of proteins from the same mRNA. HIV-1 (human immunodeficiency virus), [54] RSV (Rous sarcoma virus) [55], and all types of influenza viruses use Ribosomal Frameshift. they rely on frameshifting to create a proper ratio of normal translation and trans-frame encoded by frameshifted sequence proteins. Importantly, its use in viruses is primarily for compacting more genetic information into a shorter amount of genetic material.

\section{Effect of RNA Helicase in COVID-19}

Helicases are enzymes that are important to all living organisms. Their main action is to unpack an organism's genes. They are motor proteins that move directionally along a nucleic acid phosphodiester backbone, separating two annealed nucleic acid strands such as DNA and RNA using energy from ATP hydrolysis which proves that the vital COVID-19 is dependent on the amount of ATP production of the host cell by mitochondria. Approximately $1 \%$ of eukaryotic genes codes for helicases. 
[56] The human genome codes for 95 non-redundant helicases: 64 RNA helicases which is important in infection of SARS-CoV-2, and 31 DNA helicases. Many cellular processes, such as DNA replication, transcription, translation, recombination, DNA repair, and ribosome biogenesis involve the separation of nucleic acid strands that necessitates the use of helicases.

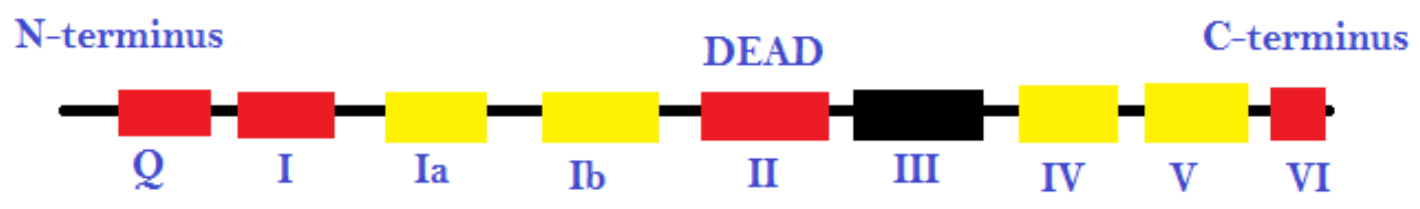

Figure (1): the different promoter sequences and accessory domains that aid in RNA unwinding. The red regions are ATP binding domains and the yellow regions are RNA interaction domains. Specific sequences termed DEAD-box proteins are also present that help catalyzes reactions in which ATP does not need to be directly hydrolyzed, as long as it binds to the domains on the strand.

This image represents the different promoter sequences and accessory domains that aid in RNA local strand separation. The red regions are ATP binding domains and the yellow regions that is RNA interaction domains.
Special sequences termed DEAD-box proteins helps catalyzes reactions in which ATP does not need to be directly hydrolyzed, as long as it binds to the domains on the strand.

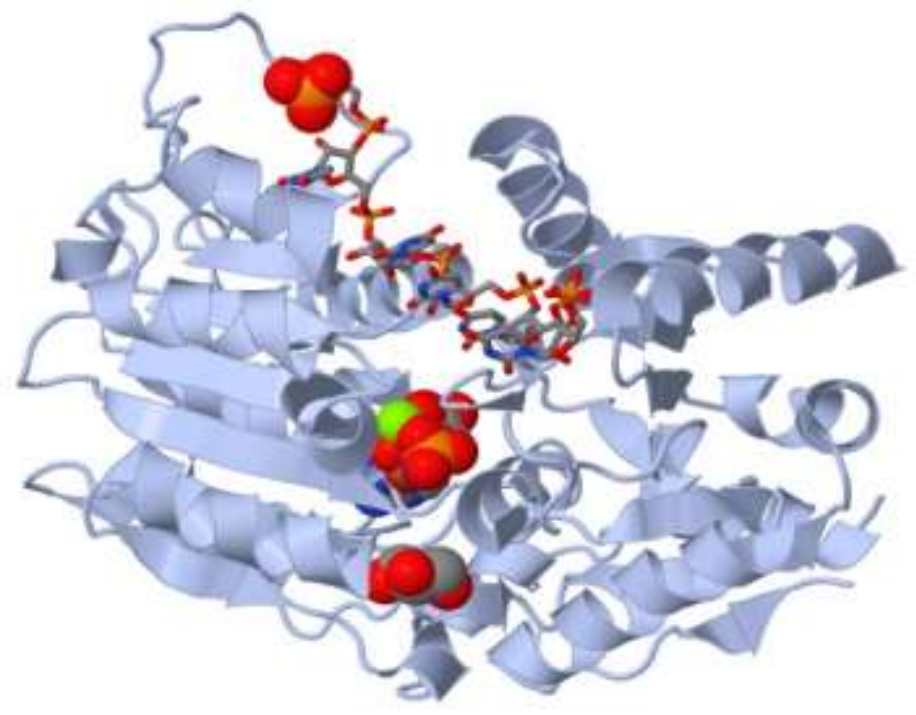

Figure2. Human DEAD-box RNA helicase

Nearly 80 percent of all viruses are RNA viruses and they contain their specific RNA helicases. [58] Defective RNA helicases have been linked to Viral Infections. [59] Some RNA helicases and DNA helicases can be found together in all the helicase super-families except for SF6. [60] [61] All the eukaryotic RNA helicases that have been identified till present days are non-ring forming and are part of SF1 and SF2. Ring-forming RNA helicases have been found in bacteria and viruses. [62] RNA helicases that do exhibit unwinding activity have been characterized by at least two different mechanisms: 1 . canonical duplex unwinding and 2. local strand separation. local strand separation happens by a process wherein the helicase enzyme is loaded at any place along with the duplex. This is usually aided by a single-strand region of the RNA, and the loading of the enzyme is accompanied by ATP binding. [60] Once the helicase and ATP are bound, local strand separation happens, which needs the binding of ATP, but not the actual process of ATP hydrolysis. [62] Presented with fewer base pairs, the duplex then dissociates without further assistance from the enzyme. This mode of unwinding is used by the DEAD/DEAH box helicases. [63]

\begin{tabular}{|l|l|}
\hline RNA helicase \\
\hline \hline Identifiers & 3.6 .4 .13 \\
\hline \hline EC number \\
\hline \hline Databases & IntEnz view \\
\hline \hline IntEnz & BRENDA entry \\
\hline \hline BRENDA
\end{tabular}




\begin{tabular}{|l|l|}
\hline ExPASy & NiceZyme view \\
\hline \hline KEGG & KEGG entry \\
\hline \hline MetaCyc & metabolic pathway \\
\hline \hline PRIAM & profile \\
\hline \hline PDB/structures & RCSB PDB PDBe/PDBsum \\
\hline
\end{tabular}

Table 1. The table shows RNA Helicases [64] [65] [66]

In Vitro, to find the specific helicase activity of COVID-19, we used fluorescence-based assays, filtration assays, a scintillation proximity assay, a time-resolved fluorescence resonance energy transfer assay, and even used Trupoint diagnostic assay to observe the Helicase Activity. Even we have used the basic strand displacement assay which had been used in 1982-1983. [67] [68] The result was interestingly showed each Virus Helicase Assay is different from the other. The reason is the environment where the virus exists/evolves rapidly and the only answer to this result is Lamarckian Evolution. As Coronaviruses Including SarSCoV-2 evolves very fast, their adaptation to the environment explains our results. [67] [68] [69]

\section{Shifting balance theory, Bateson-Dobzhansky-Muller model \&} Quantum evolution
The Bateson-Dobzhansky-Muller model, [69] is a model of the evolution of genetic incompatibility, important in comprehending the evolution of reproductive isolation during speciation and the role of natural selection (Darwin Theory) in bringing it about. The theory was first presented by William Bateson in 1909, [70] after that by Theodosius Dobzhansky in 1934, and then by Herman Muller, H. Allen Orr, and Sergey Gavrilets. [71]. This model describes the drift between two species or even viruses to become hybrid and act differently in the environment. As many scientists only focus on the Co-Evolution of the viruses, BatesonDobzhansky-Muller model can be useful in describing the Fixation and Adaptation of SARS-CoV-2 and COVID-19 in the different environment as well.

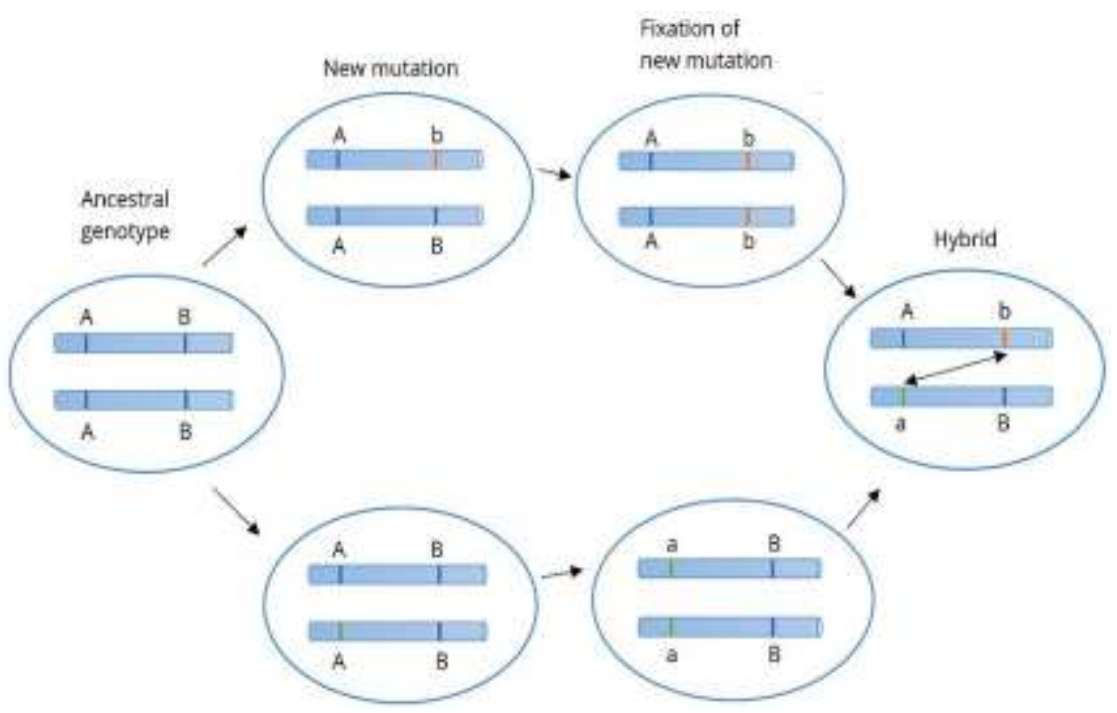

Figure3. Bateson-Dobzhansky-Muller

In the ancestral population, the genotype is AABB. When two populations become isolated from each other, new mutations can arise. In one population A evolves into $\mathrm{a}$, and in the other $\mathrm{B}$ evolves into $\mathrm{b}$. When the two populations hybridize it is the first time $\mathrm{A}$ and $\mathrm{B}$ interacts with each other. When these alleles are incompatible, we speak of DobzhanskyMuller incompatibilities.

The Shifting balance theory is another theory of evolution introduced in 1932 by Sewall Wright, suggesting that adaptive evolution may proceed most quickly when a population of viruses divides into subpopulations with restricted gene flow. attempting to explain how a population may move across an adaptive valley to a higher adaptive peak. [72] According to the theory, this movement occurs in three steps:
(1) Genetic drift: allows a locally adapted subpopulation to move across an adaptive valley to the base of a higher adaptive peak.

(2) Natural selection: will move the subpopulation up to the higher peak.

(3) This new superiorly adapted subpopulation may then expand its range and outcompete or interbreed with other subpopulations, causing the spread of new adaptations and movement of the global population toward the new fitness peak.

All three steps describe adaption, Genetic Drift, and the Fitness of SARS$\mathrm{CoV}-2$. Novel Coronavirus has been evolved so fast from their ancestors to become a new Hybrid Novel RNA Virus and like cancer cells, they have rapid genetic mutations and adaptation to the environment. 


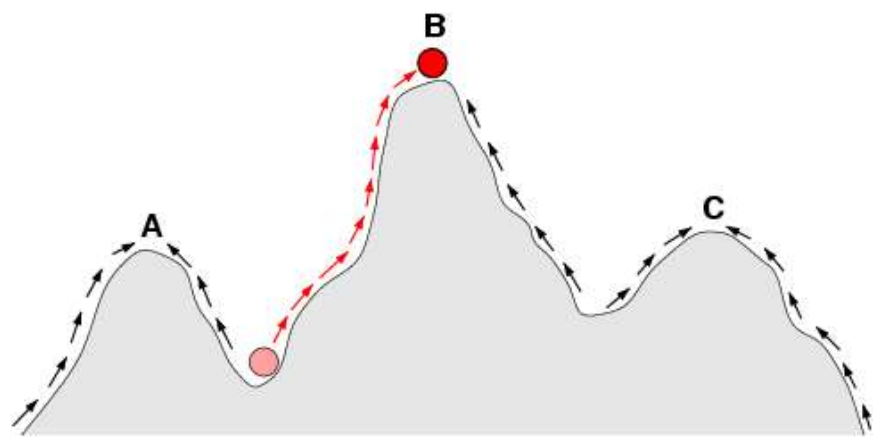

Figure 4. \{The arrows indicate the preferred flow of a population (Viruses as well) on the landscape. The red ball indicates a population (or Viruses) that moves from an adaptive valley to the top of an adaptive peak. Based on natural selection (which usually acts to increase fitness in a population), it is not possible for a population at peak A to reach peak B because this requires descending into an adaptive valley. Shifting balance theory aims to explain how this may be possible.

Quantum evolution was introduced by George Gaylord Simpson in 1953. Quantum Evolution happens at the Taxonomic level and it plays a very important role in the origin taxonomic units of relatively high rank in families, orders, and classes of species and parasites including viruses. As a whole, according to Simpson's statements in 1944, quantum evolution resulted from Sewall Wright's model of random genetic drift. [74-83]

\section{The History behind the Neglected Coronavirus}

We cannot forget the history of the outbreak of Coronaviruses. Firstly, it was considered harmless pathogens until they caused three major pandemic of severe respiratory disease in the last 20 years. The Coronavirus was recognized in 1960 [84] and it was identified as a cause of the common cold. In 2002, it was considered not fatal virus and not severely pathogenic to humans which was a mistake. Then took place across the globe when an infected doctor traveled to Hong Kong in February 2003 [85] and transmitted the infection to other health workers and guests staying in the same hotel. These patients brought infection back to their home countries, that is, Singapore, Vietnam, and Canada. In the year 2012 [86], a new coronavirus became pandemic in the Middle East and was named Middle East Respiratory Syndrome (MERS). [86-90] Based on our sessions above, the COVID-19 is a Hybrid Virus with has a high mutation rate like cancer cells and has the potential of causing a new Hybrid Pandemic in the future. The Shifting Theory, Co-Evolution, Bateson-Dobzhansky-Muller model, and Quantum Evolution are the reason behind these high rare and neglected pandemics in the last 20 years.

\section{Conclusion}

Based on our research, to find the genome sequence of COVID-19 we also used Nanopore sequencing that introduced and manufactured by Oxford scientists, due to differences in the action of infection in the host, we could not reach any results since the Novel Virus has not a stable genome which shows it is quite dynamic. since through our deep research, each virus contains its specific genome sequencing and we cannot claim that COVID-19 has one specific genome sequence like MERS-CoV, SARS-C-V or any types of viruses which has been discovered and contains their specific genome. The main reason is the quick adaptation to the environment, Temperature, humidity, host genome type, host metabolism, Genetic Drift, Recombination of the virus, the high population of human beings, and the amount of ATP production of the host by their Mitochondria and loss of MMP. Therefore; any type of vaccine cannot prevent the host from becoming infected by the virus since as we discussed, the virus is flu based. Vice versa, the new Coronavirus becomes more adapted and changes rapidly to make the environment and the host becoming weak and infected in the end.

\section{References}

1. Estola T (1970). "Coronaviruses, a New Group of Animal RNA Viruses". Avian Diseases. 14 (2): 330-336..

2. Fabricant J (1998). "The Early History of Infectious Bronchitis". Avian Diseases. 42 (4): 648-650. doi:10.2307/1592697. ISSN 0005-2086. JSTOR 1592697.

3. Decaro N (2011). "Gammacoronavirus". In Tidona C, Darai G (eds.). Gammacoronavirust: Coronaviridae. The Springer Index of Viruses. Springer. pp. 403-413. doi:10.1007/978-0-38795919-1_58. ISBN 978-0-387-95919-1. PMC 7176155.

4. McIntosh K (1974). "Coronaviruses: A Comparative Review". In Arber W, Haas R, Henle W, Hofschneider PH, Jerne NK, Koldovský P, Koprowski H, Maaløe O, Rott R (eds.). Current Topics in Microbiology and Immunology / Ergebnisse der Mikrobiologie und Immunitätsforschung. Current Topics in Microbiology and Immunology / Ergebnisse der Mikrobiologie und Immunitätsforschung. Berlin, Heidelberg: Springer. p. 87. doi:10.1007/978-3-642-65775-7_3. ISBN 978-3-642-65775-7.

5. "Il était une fois les coronavirus". Réalités Biomédicales (in French). 2020-03-27. Retrieved 2020-04-18.

6. Kahn JS, McIntosh K (November 2005). "History and recent advances in coronavirus discovery". The Pediatric Infectious Disease Journal. 24 (11 Suppl): S223-7, discussion S226. DOI: 10.1097/01.inf.0000188166.17324.60. PMID 16378050.

7. Mahase E (April 2020). "The BMJ in 1965". BMJ. 369: m1547. doi:10.1136/bmj.m1547. PMID 32299810.

8. Monto AS (1984). "Coronaviruses". In Evans AS (ed.). Viral Infections of Humans. Viral Infections of Humans: Epidemiology and Control. Springer US. pp. 151-165. doi:10.1007/978-1-46844727-9_7. ISBN 978-1-4684-4727-9.

9. Kendall EJ, Bynoe ML, Tyrrell DA (July 1962). "Virus isolations from common colds occurring in a residential school". British Medical Journal. 2 (5297): 82-6. doi:10.1136/BMJ.2.5297.82. PMC 1925312. PMID 14455113.

10. Richmond C (2005-06-18). "David Tyrrell". BMJ: British Medical Journal. $330 \quad$ (7505): 1451. doi:10.1136/BMJ.330.7505.1451. PMC 558394.

11. "Obituary Notices: Malcom Byone". British Medical Journal. 2 (5660): 827-829. 1969-06-28. doi:10.1136/BMJ.2.5660.827. 
12. Tyrrell DA, Bynoe ML (June 1965). "Cultivation of a Novel Type of Common-Cold Virus in Organ Cultures". British Medical Journal. 1 (5448): 1467-70. doi:10.1136/BMJ.1.5448.1467. PMC 2166670. PMID 14288084.

13. Tyrrell DA, Fielder M (2002). Cold Wars: The Fight Against the Common Cold. Oxford University Press. pp. 93-95. ISBN 978-019-263285-2.

14. Hagan WA, Bruner DW, Gillespie JH, Timoney JF, Scott FW, Barlough JE (1988). Hagan and Bruner's Microbiology and Infectious Diseases of Domestic Animals: Regarding Etiology, Epizootiology, Pathogenesis, Immunity, Diagnosis, and Antimicrobial Susceptibility. Cornell University Press. p. 440. ISBN 978-0-8014-1896-9.

15. Knapp, Alex. "The Secret History Of The First Coronavirus". Forbes. Retrieved 2020-05-06.

16. Hamre D, Procknow JJ (January 1966). "A new virus isolated from the human respiratory tract". Proceedings of the Society for Experimental Biology and Medicine. Society for Experimental Biology and Medicine. 121 (1): 190-3. doi:10.3181/00379727121-30734. PMID 4285768.

17. "The woman who discovered the first coronavirus".

18. Almeida J (2008-06-26). "June Almeida (née Hart)". BMJ. 336 (7659): 1511.1-1511. doi:10.1136/bmj.a434. ISSN 0959-8138. PMC 2440895.

19. Almeida JD, Tyrrell DA (April 1967). "The morphology of three previously uncharacterized human respiratory viruses that grow in organ culture". The Journal of General Virology. 1 (2): 175-8. doi:10.1099/0022-1317-1-2-175. PMID 4293939.

20. McIntosh K, Becker WB, Chanock RM (December 1967). "Growth in the suckling-mouse brain of "IBV-like" viruses from patients with upper respiratory tract disease". Proceedings of the National Academy of Sciences of the United States of America. 58 (6): 2268-73. Bibcode:1967PNAS...58.2268M. doi:10.1073/pnas.58.6.2268. PMC 223830. PMID 4298953.

21. McIntosh K, Dees JH, Becker WB, Kapikian AZ, Chanock RM (April 1967). "Recovery in tracheal organ cultures of novel viruses from patients with respiratory disease". Proceedings of the National Academy of Sciences of the United States of America. 57 (4): 933-40. Bibcode:1967PNAS...57..933M. doi:10.1073/pnas.57.4.933. PMC 224637. PMID 5231356.

22. Times, Harold M. Schmeck Jr Special To the New York (196705-05). "Six Newly Discovered Viruses May Explain Cold; Strains Are Similar to Germ That Causes a Bronchial Infection in Chickens Believed to Be New Group". The New York Times. ISSN 0362-4331. Retrieved 2020-04-25.

23. Myint SH (1995). "Human Coronavirus Infections". In Siddell SG (ed.). The Coronaviridae. The Viruses. Springer US. pp. 389-401. doi:10.1007/978-1-4899-1531-3_18. ISBN 978-1-4899-1531-3.

24. Geller C, Varbanov M, Duval RE (November 2012). "Human coronaviruses: insights into environmental resistance and its influence on the development of new antiseptic strategies". Viruses. 4 (11): 3044-68. doi:10.3390/v4113044. PMC 3509683. PMID 23202515.

25. Corman VM, Jores J, Meyer B, Younan M, Liljander A, Said MY, et al. (August 2014). "Antibodies against MERS coronavirus in dromedary camels, Kenya, 1992-2013". Emerging Infectious Diseases. 20 (8): 1319-22. doi:10.1007/978-1-4899-7448-8_10. ISBN 978-1-4899-7447-1. PMC 7122465. The other OC strains and B814 that could not be adapted to the mouse brain resisted adaptation to cell culture as well; these distinct viruses have since been lost and may have been rediscovered recently.

26. Su S, Wong G, Shi W, Liu J, Lai AC, Zhou J, et al. (June 2016). "Epidemiology, Genetic Recombination, and Pathogenesis of Coronaviruses". Trends in Microbiology. 24 (6): 490-502. doi:10.1016/j.tim.2016.03.003. PMC 7125511. PMID 27012512.

27. Zhu N, Zhang D, Wang W, Li X, Yang B, Song J, et al. (February 2020). "A Novel Coronavirus from Patients with Pneumonia in China, 2019". The New England Journal of Medicine. 382 (8): 727-733. doi:10.1056/NEJMoa2001017. PMC 7092803. PMID 31978945.

28. International Committee on Taxonomy of Viruses (2010-08-24). "ICTV Master Species List 2009—v10" (Xls).

29. Cherry, James; Demmler-Harrison, Gail J.; Kaplan, Sheldon L.; Steinbach, William J.; Hotez, Peter J. (2017). Feigin and Cherry's Textbook of Pediatric Infectious Diseases. Elsevier Health Sciences. p. PT6615. ISBN 978-0-323-39281-5.

30. "Chapter 24 - Coronaviridae". Fenner's Veterinary Virology (Fifth ed.). Academic Press. 2017. pp. 435-461. doi:10.1016/B978-012-800946-8.00024-6. ISBN 978-0-12-800946-8.

31. de Groot RJ, Baker SC, Baric R, Enjuanes L, Gorbalenya AE, Holmes KV, Perlman S, Poon L, Rottier PJ, Talbot PJ, Woo PC, Ziebuhr J (2011). "Family Coronaviridae". In King AM, Lefkowitz E, Adams MJ, Carstens EB, International Committee on Taxonomy of Viruses, International Union of Microbiological Societies. Virology Division (eds.). Ninth Report of the International Committee on Taxonomy of Viruses. Oxford: Elsevier. pp. 806-28. doi:10.1016/B978-0-12-384684-6.00068-9. ISBN 978-0-12-384684-6.

32. Wertheim JO, Chu DK, Peiris JS, Kosakovsky Pond SL, Poon LL (June 2013). "A case for the ancient origin of coronaviruses". Journal of Virology. 87 (12): 7039-45. doi:10.1128/JVI.0327312. PMC 3676139. PMID 23596293.

33. Woo PC, Lau SK, Lam CS, Lau CC, Tsang AK, Lau JH, et al. (April 2012). "Discovery of seven novels Mammalian and avian coronaviruses in the genus delta coronavirus supports bat coronaviruses as the gene source of alphacoronavirus and betacoronavirus and avian coronaviruses as the gene source of gammacoronavirus and delta coronavirus". Journal of Virology. 86 (7): 3995-4008. doi:10.1128/JVI.06540-11. PMC 3302495. PMID 22278237.

34. Forni D, Cagliani R, Clerici M, Sironi M (January 2017). "Molecular Evolution of Human Coronavirus Genomes". Trends in Microbiology. 25 (1): 35-48. DOI: 10.1016/j.tim.2016.09.001. PMC 7111218. PMID 27743750. Specifically, all HCoVs are thought to have a bat origin, except for lineage A beta-CoVs, which may have reservoirs in rodents [2].

35. Huynh J, Li S, Yount B, Smith A, Sturges L, Olsen JC, et al. (December 2012). "Evidence supporting a zoonotic origin of human coronavirus strain NL63". Journal of Virology. 86 (23): 12816-25. doi:10.1128/JVI.00906-12. PMC 3497669. PMID 22993147. If these predictions are correct, this observation suggests that HCoV-NL63 may have originated from bats between 1190 and $1449 \mathrm{CE}$.

36. Pfefferle S, Oppong S, Drexler JF, Gloza-Rausch F, Ipsen A, Seebens A, et al. (September 2009). "Distant relatives of severe acute respiratory syndrome coronavirus and close relatives of human coronavirus $229 \mathrm{E}$ in bats, Ghana". Emerging Infectious Diseases. 15 (9): 1377-84. doi:10.3201/eid1509.090224. PMC 
2819850. PMID 19788804. The most recent common ancestor of hCoV-229E and GhanaBt-CoVGrp1 existed in $\approx 1686-1800$ AD.

37. Crossley BM, Mock RE, Callison SA, Hietala SK (December 2012). "Identification and characterization of a novel alpaca respiratory coronavirus most closely related to the human coronavirus 229E". Viruses. 4 (12): 3689-700. doi:10.3390/v4123689. PMC 3528286. PMID 23235471.

38. Forni D, Cagliani R, Clerici M, Sironi M (January 2017). "Molecular Evolution of Human Coronavirus Genomes". Trends in Microbiology. 25 (1): 35-48. doi:10.1016/j.tim.2016.09.001. PMC 7111218. PMID 27743750.

39. Lau SK, Li KS, Tsang AK, Lam CS, Ahmed S, Chen H, et al. (August 2013). "Genetic characterization of Betacoronavirus lineage $\mathrm{C}$ viruses in bats reveals marked sequence divergence in the spike protein of Pipistrellus bat coronavirus HKU5 in Japanese pipistrelle: implications for the origin of the novel Middle East respiratory syndrome coronavirus". Journal of Virology. 87 (15): 8638-50. doi:10.1128/JVI.01055-13. PMC 3719811. PMID 23720729.

40. Vijaykrishna D, Smith GJ, Zhang JX, Peiris JS, Chen H, Guan Y (April 2007). "Evolutionary insights into the ecology of coronaviruses". Journal of Virology. 81 (8): 4012-20. doi:10.1128/jvi.02605-06. PMC 1866124. PMID 17267506.

41. Gouilh MA, Puechmaille SJ, Gonzalez JP, Teeling E, Kittayapong P, Manuguerra JC (October 2011). "SARS-Coronavirus ancestor's foot-prints in South-East Asian bat colonies and the refuge theory". Infection, Genetics, and Evolution. 11 (7): 1690-702. doi:10.1016/j.meegid.2011.06.021. PMC 7106191. PMID 21763784.

42. Cui J, Han N, Streicker D, Li G, Tang X, Shi Z, et al. (October 2007). "Evolutionary relationships between bat coronaviruses and their hosts". Emerging Infectious Diseases. 13 (10): 1526-32. doi:10.3201/eid1310.070448. PMC 2851503. PMID 18258002.

43. Lau SK, Woo PC, Li KS, Tsang AK, Fan RY, Luk HK, et al. (March 2015). "Discovery of a novel coronavirus, China Rattus coronavirus HKU24, from Norway rats supports the murine origin of Betacoronavirus 1 and has implications for the ancestor of Betacoronavirus lineage A". Journal of Virology. 89 (6): 307692. doi:10.1128/JVI.02420-14. PMC 4337523. PMID 25552712.

44. Bidokhti MR, Tråvén M, Krishna NK, Munir M, Belák S, Alenius S, Cortey M (September 2013). "Evolutionary dynamics of bovine coronaviruses: natural selection pattern of the spike gene implies adaptive evolution of the strains". The Journal of General Virology. 94 (Pt 9): 2036-2049. doi:10.1099/vir.0.054940-0. PMID 23804565. See Table 1

45. Vijgen L, Keyaerts E, Moës E, Thoelen I, Wollants E, Lemey P, et al. (February 2005). "Complete genomic sequence of human coronavirus OC43: molecular clock analysis suggests a relatively recent zoonotic coronavirus transmission event". Journal of Virology. 79 (3): 1595-604. doi:10.1128/jvi.79.3.15951604.2005. PMC 544107. PMID 15650185.

46. Vijgen L, Keyaerts E, Moës E, Thoelen I, Wollants E, Lemey P, et al. (February 2005). "Complete genomic sequence of human coronavirus OC43: molecular clock analysis suggests a relatively recent zoonotic coronavirus transmission event". Journal of Virology. 79 (3): 1595-604. doi:10.1128/JVI.79.3.15951604.2005. PMC 544107. PMID 15650185. However, it is tempting to speculate about an alternative hypothesis, that the 1889-1890 pandemic may have been the result of interspecies transmission of bovine coronaviruses to humans, resulting in the subsequent emergence of HCoV-OC43.

47. Corman VM, Muth D, Niemeyer D, Drosten C (2018). "Hosts and Sources of Endemic Human Coronaviruses". Advances in Virus Research. 100: 163-188. DOI: 10.1016/bs.aivir.2018.01.001. ISBN 9780128152010. PMC 7112090. PMID 29551135.

48. Lau SK, Lee P, Tsang AK, Yip CC, Tse H, Lee RA, et al. (November 2011). "Molecular epidemiology of human coronavirus OC43 reveals the evolution of different genotypes over time and recent emergence of a novel genotype due to natural recombination". Journal of Virology. 85 (21): 11325-37. doi:10.1128/JVI.05512-11. PMC 3194943. PMID 21849456.

49. Schaumburg CS, Held KS, Lane TE (May 2008). "Mouse hepatitis virus infection of the CNS: a model for defense, disease, and repair". Frontiers in Bioscience. 13 (13): 4393-406. doi:10.2741/3012. PMC 5025298. PMID 18508518.

50. Liu P, Shi L, Zhang W, He J, Liu C, Zhao C, et al. (November 2017). "Prevalence and genetic diversity analysis of human coronaviruses among cross-border children". Virology Journal. 14 (1): 230. doi:10.1186/s12985-017-0896-0. PMC 5700739. PMID 29166910.

51. Forgie S, Marrie TJ. (2009). "Healthcare-associated atypical pneumonia". Seminars in Respiratory and Critical Care Medicine. 30 (1): 67-85. doi:10.1055/s-0028-1119811. PMID 19199189.

52. Sorush Niknamian. (2020). Introducing Covid-19 as an Evolutionary Metabolic Infectious Disease (Emid) the Prime Cause and Representing Alternative Treatment for COVID-19 (SARS-CoV-2). 1:1.

53. Ivanov IP, Atkins JF (2007). "Ribosomal frameshifting in decoding antizyme mRNAs from yeast and protists to humans: close to 300 cases reveal remarkable diversity despite underlying conservation". Nucleic Acids Research. 35 (6): 1842-1858. doi:10.1093/nar/gkm035. PMC 1874602. PMID 17332016.

54. Jacks T, Power MD, Masiarz FR, Luciw PA, Barr PJ, (1988). "Characterization of ribosomal frameshifting in HIV-1 gag-pol expression". Nature; 331 (6153): 280-283. Bibcode: Natur. 331..280J. doi:10.1038/331280a0. PMID 2447506.

55. Jacks T, Power MD, Masiarz FR, Luciw PA, Barr PJ, (1988). "Characterization of ribosomal frameshifting in HIV-1 gag-pol expression". Nature; 331 (6153): 280-283. Bibcode: Natur. 331..280J. doi:10.1038/331280a0. PMID 2447506.

56. Jacks T, Madhani HD, Masiarz FR, Varmus HE. (1988). "Signals for ribosomal frameshifting in the Rous sarcoma virus gag-pol region". Cell; 55 (3): 447-458. doi:10.1016/00928674(88)90031-1. PMID 2846182.

57. Venkatesan M, Silver LL, Nossal NG (1982). "Bacteriophage T4 gene 41 protein, required for the synthesis of RNA primers, is also a DNA helicase". J. Biol. Chem; 257 (20): 12426-34. PMID 6288720 .

58. Matson SW, Tabor S, Richardson CC. (1983). "The gene 4 protein of bacteriophage T7. Characterization of helicase activity". J. Biol. Chem; 258 (22): 14017-24. PMID 6315716.

59. Steimer, L.; Klostermeier, D. (2012). "RNA helicases in infection and disease". RNA Biology; 9 (6): 751-771. doi:10.4161/rna.20090. PMID 22699555.

60. Jankowsky E, Fairman-Williams ME (2010). "An introduction to RNA helicases: superfamilies, families, and major themes". In Jankowsky E (ed.). RNA Helicases (RSC Biomolecular Sciences). 
Cambridge, England: Royal Society of Chemistry; p. 5. ISBN 9781-84755-914-2.

61. Ranji, A.; Boris-Lawrie, K. (2010). "RNA helicases: Emerging roles in viral replication and the host innate response". RNA Biology; 7 (6): 775-787. doi:10.4161/rna.7.6.14249. PMC 3073335. PMID 21173576.

62. Jankowsky E (2011). "RNA helicases at work: binding and rearranging". Trends Biochem. Sci. 36 (1): 19-29. DOI: 10.1016/j.tibs.2010.07.008. PMC 3017212. PMID 20813532.

63. Yang Q, Del Campo M, Lambowitz AM, Jankowsky E. (2007). "DEAD-box proteins unwind duplexes by local strand separation". Mol. Cell; 28 (2): 253-63. DOI: 10.1016/j.molcel.2007.08.016. PMID 17964264.

64. Liu F, Putnam A, Jankowsky E (2008). "ATP hydrolysis is required for DEAD-box protein recycling but not for duplex unwinding". Proc. Natl. Acad. Sci; U.S.A. 105 (51): 20209-14. Bibcode:2008 PNAS.10520209L. doi:10.1073/pnas.0811115106. PMC 2629341. PMID 19088201.

65. Jarmoskaite I, Russell R (2011). "DEAD-box proteins as RNA helicases and chaperones". Wiley Interdiscip Rev RNA; 2 (1): 13552. doi:10.1002/wrna.50. PMC 3032546. PMID 21297876.

66. Lainé JP, Mocquet V, Egly JM (2006). TFIIH enzymatic activities in transcription and nucleotide excision repair. Meth. Enzymol. Methods in Enzymology; 408. 246-63. doi:10.1016/S00766879(06)08015-3. ISBN 9780121828134. PMID 16793373.

67. Darwin, Charles (1871). "Pangenesis".Nature;3(78): 502-503.

68. Holterhoff, Kate (2014). "The History and Reception of Charles Darwin's Hypothesis of Pangenesis". Journal of the History of Biology; 47 (4): 661-695. doi:10.1007/s10739-014-9377-0. PMID 24570302. S2CID 207150548.

69. Liu, Yongsheng (2008). "A new perspective on Darwin's Pangenesis". Biological Reviews; 83 (2): 141-149. doi:10.1111/j.1469-185x.2008.00036. x. PMID 18429766. S2CID 39953275.

70. Orr HA (1996). "Dobzhansky, Bateson, and the genetics of speciation". Genetics; 144 (4): 1331-5. PMC 1207686. PMID 8978022.

71. Bateson W (1909). "Heredity and variation in modern lights". Darwin and Modern Science; 85-101. doi:10.1017/cbo9780511693953.007. ISBN 9780511693953.

72. Dobzhansky T (1934). "Studies on Hybrid Sterility. I. Spermatogenesis in pure and hybrid Drosophila pseudoobscura". Zeitschrift für Zellforschung und mikroskopische Anatomie. 21 (2): 169-221. doi:10.1007/bf00374056. Archived from the original on 2012-03-27.

73. Coyne; Barton, Turelli (1997). "Perspective: a critique of Sewall Wright's shifting balance theory of evolution". Evolution; 3. 51: 643-671. doi:10.2307/2411143. PMID 28568586.

74. Coyne; Barton, Turelli (2000). "Is Wright's shifting balance process important in evolution?". Evolution; 1. 54: 306-317. doi:10.1111/j.0014-3820. 2000.tb00033. x.

75. Gould, S. J. (1980). "G. G. Simpson, Paleontology and the Modern Synthesis." In E. Mayr and W. B. Provine, eds., The Evolutionary Synthesis. Cambridge MA: Harvard University Press, pp. 153172.
76. Simpson, G. G. (1953). The Major Features of Evolution. New York: Columbia Univ. Press, p. 389.

77. Simpson, G. G. (1944). Tempo and Mode in Evolution. New York: Columbia Univ. Press, p. 206.

78. Grant, Verne (1963). The Origin of Adaptations. New York and London: Columbia University Press. pp. 606.

79. Lewis, Harlan; Raven, Peter H. (1958). "Rapid Evolution in Clarkia". Evolution; 12 (3): 319-336. doi:10.1111/j.1558-5646. 1958.tb02962. x.

80. Lewis, Harlan (1962). "Catastrophic Selection as a Factor in Speciation". Evolution; 16 (3): 257-271. doi:10.1111/j.15585646. 1962.tb03218. $\mathrm{x}$.

81. Lewis, Harlan; Raven, Peter H. (1958). "Rapid Evolution in Clarkia". Evolution. 12 (3): 319-336. doi:10.1111/j.1558-5646. 1958.tb02962. x.

82. Lewis, Harlan (1962). "Catastrophic Selection as a Factor in Speciation". Evolution. 16 (3): 257-271. doi:10.1111/j.15585646. 1962.tb03218. x.

83. Gottlieb, L.D. (2003). "Rethinking classic examples of recent speciation in plants". New Phytologist. 161: 71-82. doi:10.1046/j.1469-8137.2003.00922. x.

84. Gottlieb, L.D. (1973). "Genetic Differentiation, Sympatric Speciation, and the Origin of a Diploid Species of Stephanomeria". American Journal of Botany. 60 (6): 545-553. doi:10.2307/2441378. JSTOR 2441378.

85. Simpson, G. G. (1953). The Major Features of Evolution, p. 390.

86. Gould, S. J. (1983). "The hardening of the Modern Synthesis" In Marjorie Grene, ed., Dimensions of Darwinism. Cambridge UK: Cambridge University Press, pp. 71-93.

87. Marra MA, Jones SJ, Astell CR, et al. The genome sequence of the SARS-associated coronavirus. Science. 2003; 300:1399-1404.

88. Zhong NS, Zeng GQ. Our strategies for fighting severe acute respiratory syndrome (SARS). Am J Respir Crit Care Med. 2003; 168:7-9.

89. Bell D, Jenkins P, Hall J. World Health Organization global conference on the severe acute respiratory syndrome. Emerg Infect Dis. 2003 Sep;9(9): 1191-1192.

90. Aleanizy FS, Mohmed N, Alqahtani FY, El Hadi Mohamed RA. An outbreak of Middle East respiratory syndrome coronavirus in Saudi Arabia: a retrospective study. BMC Infect Dis. 2017; 17:23.

91. Haagmans BL, Al Dhahiry SH, Reusken CB, et al. Middle East respiratory syndrome coronavirus in dromedary camels: an outbreak investigation. Lancet Infect Dis. 2014; 14:140-145.

92. Conforti C, Giuffrida R, Dianzani C, Di Meo N, Zalaudek I. COVID-19, and psoriasis: is it time to limit treatment with immunosuppressants? A call for action. Dermatol Ther. 2020;11: e13298.

93. Yan Y, Chen H, Chen L, et al. Consensus of Chinese experts on protection of skin and mucous membrane barrier for healthcare workers fight-ing against coronavirus disease 2019. Dermatol Ther. 2020;13: e13310.

94. Li Q, Guan X, Wu P, et al. Early transmission dynamics in Wuhan, China, of novel coronavirus-infected pneumonia. $N$ Engl J Med. 2020, Jan 29;382:119 9-1207. 